\title{
Evaluation of Spiced Ready-to-Serve Beverage Prepared form Wild Edible under-Utilized Bhamora (Benthamidiacapitata (Wallich Ex Roxb.) Hara) Fruit
}

\author{
Ghan Shyam Abrol ${ }^{1 *}$, V K Joshi ${ }^{2}$ and B P Nautiyal ${ }^{3}$ \\ ${ }^{1}$ College of Horticulture, Rani Lakshmi Bai Central Agricultural University, India \\ ${ }^{2}$ Department of Food Science and Technology, Dr YS Parmar Univeristy of Horticulture and Forestry, India \\ ${ }^{3}$ Department of Medicinal and Aromatic Plants, College of Horticulture, India
}

*Corresponding author: Ghan Shyam Abrol, College of Horticulture, Rani Lakshmi Bai Central Agricultural University, Jhansi-284003, India

Submission: October 11, 2017; Published: February 26, 2018

\begin{abstract}
Bhamora fruit (Benthamidiacapitata (Wallich ex Roxb.) Hara) is found growing wild at higher altitude of Himalayas. The fruit is utilized by the farmers for table purpose only and most of produce goes waste. The present study was carried out to evaluate the functional properties of fruit and to standardize the best combination of bhamora juice and spices extract to prepare bhamora spiced RTS (Ready-to-Serve) beverage. The bhamora fruit found to have an average $38.20 \mathrm{~mm}$ length, $36.35 \mathrm{~mm}$ breath and $47.71 \mathrm{~g}$ weight. The fruit contains a good amount of total soluble solids $16.2{ }^{\circ} \mathrm{B}$, a higher amount of titratable acidity $2.16 \%$ as citric acid, reducing and total sugars $7.22 \%$ and $11.42 \%$ respectively. The antioxidant properties; ascorbic acid $248.40 \mathrm{mg} / 100 \mathrm{~g}$ while total phenolics and total anthocyanin was $493.12 \mathrm{mg} / 100 \mathrm{~g}$ and $282.75 \mathrm{mg} / 100 \mathrm{~g}$ respectively. In the bhamora spiced RTS beverage, antioxidant property as ascorbic acid found to be ranged between 30.8 to $32.6 \mathrm{mg} / 100 \mathrm{~g}$, total phenols from $145.1 \mathrm{to} 203.5 \mathrm{mg} / 100 \mathrm{~g}$ and total anthocyanin 64.01 to 76.23 in treatments from $\mathrm{ST}_{1}$ to $\mathrm{ST}_{6}$. On the basis of sensory, RTS beverage prepared with $25 \%$ juice content along with spices extract i.e. treatment $\mathrm{ST}_{4}$ adjudged as best.
\end{abstract}

Keywords: Bhamora fruit; Wild edible under-utilized fruit; Spiced RTS beverages

\section{Introduction}

Bhamora (Benthamidiacapitata (Wallich ex Roxb.) Hara) belongs to family Cornaceae and found growing wild at higher altitude of Himalayas at $1500-2200 \mathrm{~m}$ abs 1 [1]. The fruit locally is known as Bhamora, Guldhara, Gulna and Thamia while English name of the fruit is Himalayan strawberry, Bentham's Cornel, Headed-flowered dogwood, Mountain moon, Evergreen dogwood, Himalayan flowering dogwood etc. The duration of availability of fruit is from June to July. The fruit is collected by the villagers for table purpose only. Though, the most of the production goes waste due to no technical know-how poor market demand and less processing avenues. Further, the two cultivars out of which one is bitter and one is sweet after ripening are found growing naturally at higher hills of western Himalayas. Presently, spice-based beverages are gaining importance in the market place [2]. Antioxidant and sensory properties of RTS beverages prepared from juices such as plum, watermelon, apple and pineapple was increased by addition of spice extracts like ginger, black pepper, mint, cardamom and cumin [3-6]. These spice apart from their appetizing properties, also possess medicinal and therapeutic values, which have a profound effect on human health, since they affect many functional processes [6]. Spices in foods are primarily used for their flavour and stability in storage and have natural antioxidants and antimicrobial properties apart from having carminative effect and also aid in digestion through the stimulation of appetite [7]. Thus, addition of herbal extract to bhamora pulp might attract good response from the consumers as an appetizer. Keeping all these points in view, the present investigation was undertaken for preparation spiced ready-to-serve from bhamora fruit. Moreover physico-chemical and antioxidant properties of bhamora fruits have never been reported before this study.

\section{Materials and Methods}

\section{Raw material}

Mature bhamora fruits were collected from the wild forest surrounding the College of Horticulture, VCSG Uttarakhand University of Horticulture and Forestry, Bharsar, Pauri Garhwal. Fruits were sorted and washed thoroughly with water to remove adherent foreign materials. The fruits were hot pulped to prepare pulp. The extracted pulp was then used for the preparation of spiced RTS beverage. Spices such as cardamom, cumin and black pepper were dried in an oven at $60{ }^{\circ} \mathrm{C}$ for $24 \mathrm{~h}$ and ground in the Super Mixer Grinder (Model MX-1155). Fresh ginger was washed 
thoroughly, peeled manually and passed through a screw type juice extractor to extract juice. Fresh mint leaves were washed, crushed in a blender and squeezed through muslin cloth to get extract. All the spices and herbs were use as previously standardized for plum spiced RTS by Joshi et al. [8] and detail is given in Table 1 .

Table 1: Quantities of spices and herbs used for 1 litre of the product (spiced RTS) (Joshi et al. [8])

\begin{tabular}{|c|c|}
\hline Particulars & Quantity \\
\hline Cardamom (g) & 0.3 \\
\hline Cumin (g) & 0.8 \\
\hline Black pepper (g) & 0.8 \\
\hline Common salt (g) & 3 \\
\hline Black salt (g) & 2 \\
\hline Ginger extract (ml) & 3 \\
\hline Mint extract (ml) & 2 \\
\hline
\end{tabular}

\section{Preparation of spiced RTS beverages}

The bhamora fruit beverage was prepared with a varying amount of juice content of 20, 25 and $30 \%$ and each concentration was further divided for with or without spices extract, thus there were six treatments from $\mathrm{ST}_{1}$ to $\mathrm{ST}_{6}$. The spiced RTS beverages were prepared according to standard method. The pre-determined quantities of spices were boiled in $100 \mathrm{ml}$ of water, strained through muslin cloth and added to the mixture of pulp and sugar syrup. Finally, mint and ginger extracts were added as per recipes and the contents were mixed thoroughly [9]. The TSS was kept to $15^{\circ} \mathrm{B}$ with sugar syrup. The beverages were then hot filled $\left(85^{\circ} \mathrm{C}\right)$ in precleaned sterilized glass bottles of $200 \mathrm{ml}$ capacity, crown corked, labelled and kept for further analysis.

\section{Physico-chemical analysis}

Physiological loss in weight

Physiological loss in weight (PLW) of bhamora fruit was calculated after every 5 th day for 20 days and the results were then expressed in percentage [10] using following formula:

$$
\text { PLW }(\%)=\frac{\text { Initial Weight }- \text { Final weight }}{\text { Initial weight }} \times 100
$$

\section{Total soluble solids (TSS)}

TSS of fresh fruit and spiced beverages were measured using Erma hand Refractometer. The results were expressed as degree Brix $(\mathrm{oB})$. The readings were corrected by applying the correction factor for the temperature variation [10].

\section{Titratable acidity}

Titratable acidity was estimated by titrating a known volume of the sample against standard $0.1 \mathrm{~N} \mathrm{NaOH}$ solutions by using phenolphthalein as an indicator up to the end point (pink colour) The titratable acidity was expressed as per cent citric acid [10]. Titratable acidity $(\%)=\frac{\text { Titre } \times \text { Normality of alkali } \times \text { volume made up } \times \text { equivalent weight of acid }}{\text { Vol }} \times 100$

\section{Reducing and Total sugars}

$$
\text { Vol./ wt. of sample taken } \times \text { volume of aliquot taken } \times 1000
$$

A known weight of sample (25g) was taken in a $250 \mathrm{~mL}$ volumetric flask and $100 \mathrm{~mL}$ water was added to it. Solution was neutralized with $1 \mathrm{~N} \mathrm{NaOH}$ and $2 \mathrm{~mL}$ of $45 \%$ lead acetate was added to it and kept for $10 \mathrm{~min}$. Excess of lead acetate was removed from the sample by using $2 \mathrm{~mL}$ of $22 \%$ potassium oxalate in $250 \mathrm{~mL}$ volumetric flask. After diluting it up to the mark, the solution was filtered and clear filtrate was taken to estimate reducing sugars by titrating against a known quantity of Fehling's A and Fehling's B solution using methylene blue as an indicator [11]. Reducing sugars were estimated as per cent and calculated as given below:

Reducing sugars $(\%)=\frac{\text { Factor } \times \text { Dilution }}{\text { Titre value } \times \text { Weight of sample taken }} \times 100$

Total sugars were estimated by adding $5 \mathrm{~g}$ of citric acid to $50 \mathrm{~mL}$ calibrated sample solution and heating it for $10 \mathrm{~min}$. For complete inversion of sugars, neutralizing with $\mathrm{NaOH}$ and making volume $250 \mathrm{~mL}$ in volumetric flask was done. The total sugars were estimated as per cent and calculated as given as under:

Total sugars as invert sugars $(\%)=\frac{\text { Factor } \times \text { Dilution }}{\text { Titre } \times \text { Weight of sample taken }} \times 100$

$\%$ Sucrose $=(\%$ total invert sugars $-\%$ reducing sugars $) \times 0.95$

$\%$ Total sugars $=(\%$ reducing sugars $+\%$ sucrose $)$

\section{Quantitative analysis of antioxidant compounds}

Ascorbic Acid: Ascorbic acid content was determined as per standard AOAC method [10] using 2, 6-dichlorophenol indophenol dye. The sample extracted in $3 \% \mathrm{~m}$-phosphoric acid was titrated with the dye to an end point of pink colour. Results were expressed as mg per $100 \mathrm{~g}$ of sample and calculated by using the following formula:

Ascorbic acid $(\mathrm{mg} / 100 \mathrm{~g})=\frac{\text { Titre } \times \text { Dye factor } \times \text { volume made up }}{\text { Aliquot of extract taken } \times \text { Weight of sample taken }} \times 100$

\section{Total phenolics}

The amounts of total phenolics in the fruits and spiced beverage were determined with the Folin-Ciocalteu reagent according to the method of Bray \& Thorpe [12] using catechol as a standard. One gram of sample was taken and grinded with $10 \mathrm{~mL}$ of 80 percent ethanol in pestle and mortar, and centrifuged for $20 \mathrm{~min}$ at 1000 rpm and filtered. Filtrate was evaporated in oven up to dryness and dried extract was dissolved in $5 \mathrm{~mL}$ distilled water. $0.2-2.0 \mathrm{~mL}$ aliquot was taken in separate test tubes and volume was made up to $3 \mathrm{~mL}$. Then $0.5 \mathrm{~mL}$ Folin-Ciocalteu reagent was added. After $3 \mathrm{~min} 2 \mathrm{~mL}$ of Na2CO3 (20\%) was added and mixed. Test tubes were placed in boiling water bath for one min and then cooled. Optical density of the sample was recorded at $650 \mathrm{~nm}$ with the help of Spectronic- 20 . The concentration was determined as per the standard procedure from the standard curve. The standard curve was prepared using different concentrations $(8-32 \mu \mathrm{g} / \mathrm{mL})$ of catechol and results were expressed as mg per $100 \mathrm{~g}$ on fresh weight basis.

\section{Total anthocyanins}

Total anthocyanins present in the samples were determined by the method given by [11]. The procedure involved extraction of the anthocyanins with ethanolic-HCl and measurement of colour at the wavelength of $535 \mathrm{~nm}$ against blank of ethanolic- $\mathrm{HCl}$ using a UV-Vis spectrophotometer. The anthocyanins were calculated and expressed as mg per $100 \mathrm{~mL}$ using the formula given below: 
Total OD / $100 \mathrm{~mL}=\frac{\text { Optical Density }(O D) \times \text { Volume made up of the extructs used for colour } \times \text { Total volume meassurement }}{\text { Volume of extract used } \times \text { Volume of sample taken }} \times 100$

Where, $\mathrm{X}=$ Total OD/100 mL

$\mathrm{E}=$ Extinction coefficient (98.2)

\section{Sensory evaluation}

The sensory evaluation of the product was conducted by a panel of 5 semi-trained judges. Each sample was evaluated for colour, taste, flavour, body and overall acceptability on a composite scale [13]. The judges were provided with samples in separate booth/chambers. They were allowed to rinse their mouth with water during sensory evaluation. The evaluation was got conducted on the prescribed performa. The composite performa had score as color $=20$, taste $=40$, flavor $=20$ and body $=20$.

\section{Statistical analysis}

Each analysis assay was done five times from the fruit and bhamora spiced RTS sample to determine reproducibility. Results were expressed as mean values \pm standard deviations. One-way analysis of variance (ANOVA) was used to test any difference in properties of different treatments after the enhancement of juice content and spices extract addition. Significance difference between means was tested by using Tukey's test using S-plus for Windows (version 8.0.4).

\section{Results and Discussion}

\section{Physico-chemical and antioxidant properties of fruit}

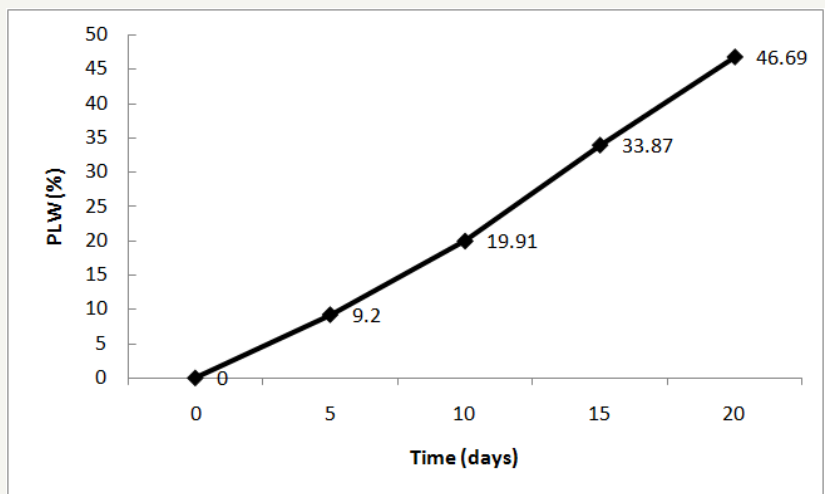

Figure 1: Per cent physiological loss in weight (PLW \%) of bhamora fruit

Physico-chemical and antioxidant properties pertaining to bhamora fruit has been shown at Table 2 . The bhamora fruits were found to contain an average $38.20 \mathrm{~mm}$ length, $36.35 \mathrm{~mm}$ breath and $47.71 \mathrm{~g}$ weight. The fruit contains a good amount of total soluble solids $16.2^{\circ} \mathrm{B}$, a higher amount of titratable acidity $2.16 \%$ as citric acid, reducing and total sugars $7.22 \%$ and $11.42 \%$, respectively. The fruits were also evaluated for its various antioxidant properties viz. Ascorbic acid $248.40 \mathrm{mg} / 100 \mathrm{~g}$ while total phenolics and total anthocyanin was $493.12 \mathrm{mg} / 100 \mathrm{~g}$ and $282.75 \mathrm{mg} / 100 \mathrm{~g}$ respectively. The fruit was globular in size, highly acidic and acrid in taste. It may be because of high phenolic content (493mg/ 100g) of the fruit. Gradually, the fruit becomes sweet in taste after ripening.
Vitamin C is an essential nutrient for humans and an important antioxidant compound that forms part of our daily diet [14]. Not only it is required for a number of essential metabolic reactions, but it is also an important agent against oxidative stress. It additionally has a role in reducing the tocopheryl radical back to its active form in the membranes of cells [15] and has even been found to have anticancer effects [16]. Ascorbic acid is highly bioavailable and is consequently the most important water soluble antioxidant vitamin in cells, effectively scavenging reactive oxygen species (ROS). When relating the antioxidant activities of fruit juices to health and disease risk, it is important to consider the contribution of ascorbic acid in addition to that of phenolic compounds with antioxidant activity [17]. In addition to ascorbic acid, many other organic acids and phenolic compounds are also present in fruits that exhibit potential biological activities such as antioxidant, antiinflammatory, antimicrobial, anticancer etc. [18]. The antioxidant activity of phenolic compounds is mainly due to their reducing properties which allow them to act as metal chelators, absorb and neutralize free radicals [19]. Based on the results obtained (Figure 1) for per cent physiological losses in weight (\%PLW) showed that the fruit has a poor shelf-life. Moreover, there is no standardized recipe available for the fruits, so present study was carried out to prepare spiced RTS, which can be a new acceptable product in the market.

Table 2: Physico-chemical and antioxidant properties of bhamora fruit

\begin{tabular}{|c|c|}
\hline Parameters & Means \pm Standard deviation* \\
\hline 1. Physical & \\
\hline a. Length $(\mathrm{mm})$ & $38.20 \pm 4.46$ \\
\hline b. Breadth (mm) & $36.35 \pm 2.29$ \\
\hline c. Weight (g) & $47.71 \pm 5.53$ \\
\hline 2. Biochemical & \\
\hline a. Total soluble solids $\left({ }^{\circ} \mathrm{B}\right)$ & $16.2 \pm 0.4$ \\
\hline b. Titratable acidity (\% CA) & $2.16 \pm 0.16$ \\
\hline c. Reducing sugars (\%) & $7.22 \pm 0.31$ \\
\hline d. Total sugars (\%) & $11.42 \pm 0.44$ \\
\hline 3. Antioxidants & \\
\hline a. Ascorbic acid (mg/ 100g) & $248.40 \pm 0.22$ \\
\hline b. Total phenols (mg/ 100g) & $493.12 \pm 0.35$ \\
\hline c. Total anthocyanin (mg/ 100g) & $282.75 \pm 0.18$ \\
\hline
\end{tabular}

*All data are the mean \pm SD of five replicates

\section{Spiced RTS beverage}

Physico-chemical characteristics: Physico-chemical characteristics of spiced RTS from bhamora fruit is shown in Table 3. The TSS of all the treatments was adjudged to $15{ }^{\circ} \mathrm{B}$ while all other parameters showed a change with the addition of spices extract and change in juice content with advancement of different treatments. The titratable acidity was ranged from 0.26 to $0.38 \%$ as CA. As the juice content and spices extract increased in treatments from $\mathrm{ST}_{1}$ to $\mathrm{ST}_{2}$, so the titratable acidity also increased. A similar trend of acidity was observed in reducing and total sugars. The reducing and total sugars among the different treatment found to 
be ranged from 7.8 to $8.6 \%$ and 11.5 to $12.4 \%$ respectively. With the increment in juice content the enhanced results of reducing and total sugars was observed. Addition of spices extract also resulted in small increase in reducing and total sugars content. A positive effective of the spices extract addition was observed in mangopineapple spiced beverage [20], mango-herbal (lemon grass) beverage [21], spiced RTS from Tamarind fruit [22] and Spiced Pineapple Ready-To-Serve Beverages [1].

Table 3: Physico-chemical characteristics of bhamora RTS with or with-out spices.

\begin{tabular}{|c|c|c|c|c|c|}
\hline Treatment & TSS $\left({ }^{\circ} \mathrm{B}\right)$ & Titratable acidity (\%) & pH & Reducing sugars (\%) & Total sugars (\%) \\
\hline ST1 & $15.0^{\mathrm{a}}$ & $0.26^{\mathrm{a}}$ & $3.83^{\mathrm{f}}$ & $7.8^{\mathrm{a}}$ & $11.5^{\mathrm{a}}$ \\
\hline ST2 & $15.0^{\mathrm{a}}$ & $0.29^{\mathrm{b}}$ & $3.77^{\mathrm{e}}$ & $8.1^{\mathrm{b}}$ & $11.9^{\mathrm{c}}$ \\
\hline ST3 & $15.0^{\mathrm{a}}$ & $0.32^{\mathrm{c}}$ & $3.52^{\mathrm{d}}$ & $8.1^{\mathrm{b}}$ & $11.7^{\mathrm{b}}$ \\
\hline ST4 & $15.0^{\mathrm{a}}$ & $0.34^{\mathrm{d}}$ & $3.48^{\mathrm{c}}$ & $8.3^{c}$ & $12.2^{\mathrm{d}}$ \\
\hline ST5 & $15.0^{\mathrm{a}}$ & $0.35^{\mathrm{d}}$ & $3.44^{\mathrm{b}}$ & $8.4^{\mathrm{c}}$ & $11.9^{c}$ \\
\hline ST6 & $15.0^{\mathrm{a}}$ & $0.38^{\mathrm{e}}$ & $3.20^{\mathrm{a}}$ & $8.6^{\mathrm{d}}$ & $12.4^{\mathrm{e}}$ \\
\hline
\end{tabular}

*All data are the mean \pm SD of five replicates. Mean followed by different letters in the same column differs significantly ( $\mathrm{p} \leq 0.05)$

Antioxidant properties: Keeping in view medicinal properties of fruit and its product, analysis of antioxidant properties of bhamora spiced RTS is done and is shown in Figure 2. Antioxidant property as ascorbic acid found to be ranged from 30.8 to $32.6 \mathrm{mg} / 100 \mathrm{~g}$ in treatments from ST1 to ST2. The results of spices addition did not affect much as the extract was almost absent in ascorbic acid content and a similar variation was observed anthocyanin content. While, distinct results were obtained in the phenolics content among all the treatments, as spices extract was rich in total phenols and thus there addition resulted in increased amount of total phenols in spiced RTS than that of without spiced RTS. Enhancement of antioxidant properties by the addition of spices extract was also reported previously in papaya RTS spiced beverage [23] and Spiced Pineapple Ready-To-Serve Beverages [1].

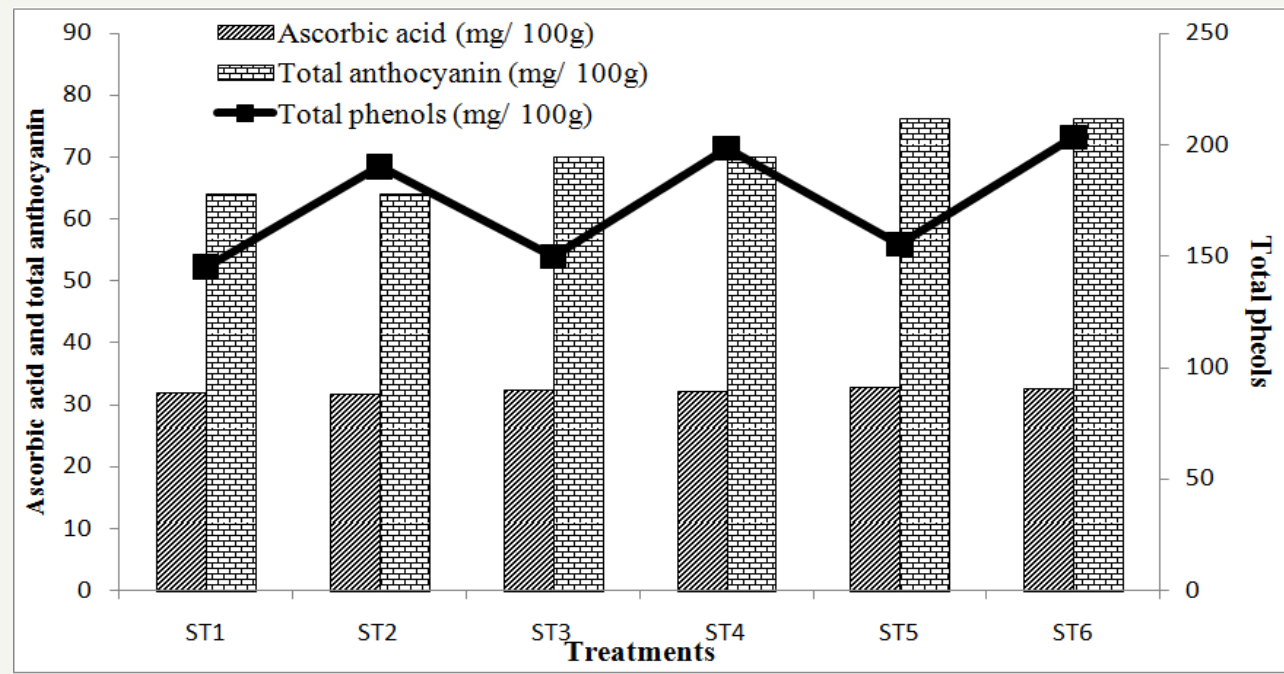

Figure 2: A Comparison in ascorbic acid, total anthocyanin and total phenols of different treatments of bhamora spiced RTS

\section{Sensory evaluation}

Data pertaining to various sensory attributes of spiced RTS of bhamora is presented in Figure 3. In general, the beverage prepared with addition of spices extract shown a better results over without spiced RTS for all the sensory attributes kept under study. It is apparent from the results that higher juice content imparted better colour appeal to the product. Further, the RTS prepared with addition of spiced extract scored better for taste and flavour attributes than those without spices extract. It is apparently attributed to the liking of consumers for spicy product. Moreover, bhamora fruit does not have that strong flavour as mango and pineapple, thus spicy taste dominates the score. Similar finding were observed by Joshi et al.
$[5,8]$ in spiced apple wine and plum appetizer, respectively. In body, RTS beverage prepared with higher juice content along with spices extract scored better. In overall, RTS beverage prepared with $25 \%$ juice content along with spices extract i.e. treatment ST4 adjudged as best.

\section{Conclusion}

Addition of juice content and spices extract enhanced the quality by improving the antioxidants and sensory properties of bhamora beverages. Juice content $25 \%$ with spices extract adjudged best combination on the basis of physico-chemical, antioxidant and sensory properties. The standardized product is easy to prepare and it has scope of commercialization. 


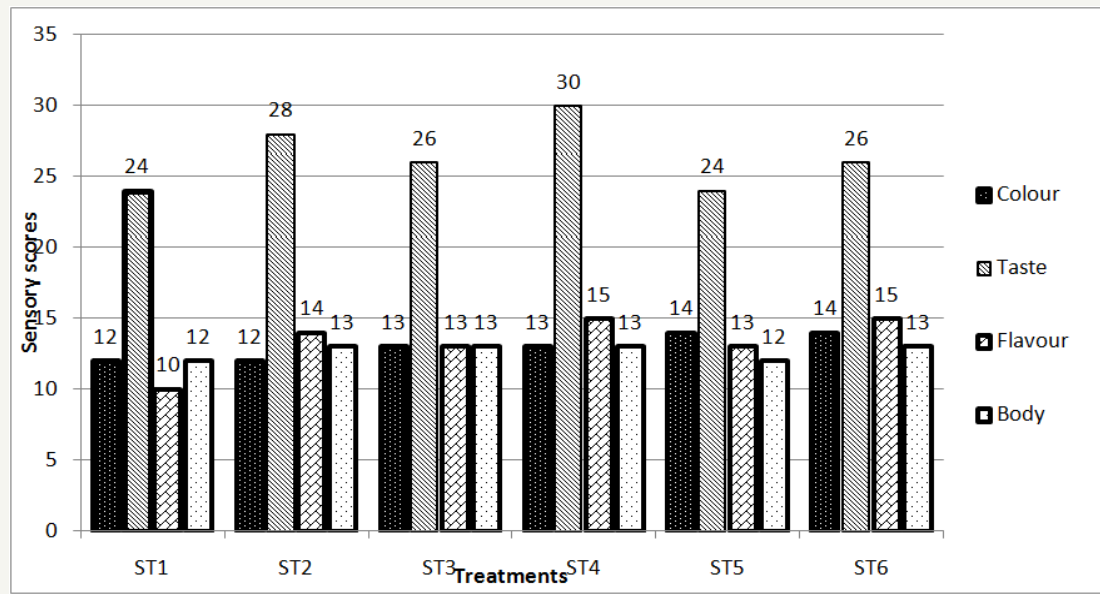

Figure 3: Sensory scores of different treatments of bhamora spiced RTS.

\section{References}

1. Radha B, Rawat DS, Tiwari JK (2013) Wild Edible Plant Resources of the Lohba Range of Kedarnath Forest Division (KFD), Garhwal Himalaya, India. Int Res J Bio Sci 2: 65-73.

2. Barrett DM, Somogyi L, Ramaswamy H (2004) Processing Fruits: Science and technology, (2 ${ }^{\text {nd }}$ edn.) CRC Press, Florida, USA.

3. Lal BB, Joshi VK, Sharma RC, Sharma R (1999) Preparation and evaluation of apple and ginger-based squash. J Sci Ind Res 58(07): 530-532.

4. Ramakrishnan L, Anuruby S (2004) Effect of selected spicemix on the quality characteristics of fruit juices. Bev Food World 31: 55-56.

5. Joshi VK, John S, Abrol GS (2014) Effect of addition of extracts of different herbs and spices on fermentation behaviour of apple must to prepare wine with medicinal value. National Acad Sci Let 37(6): 541-546.

6. Amaravathi T, Vennila P, Hemalatha G, Parimalam P (2014) Spiced Pineapple Ready-To-Serve Beverages, Indian J Sci Tech 7(11): 1827-1831.

7. Griffin J (1992) Spicing up food profits. Food Ind 45(11): 7-21.

8. Joshi VK, Sharma R, Abrol GS, Sharma R (2011) Screening of plum cultivars for preparation of ready-to-serve beverages. Bio-processing Food 107-113.

9. Sharma R, Barwal VS, Kaushal BBL (2002) Preparation and evaluation of spiced plum squash. Bev Food World 29: 23-26.

10. AOAC (2000) Official Methods of Analysis. Association of Official Analytical Chemists, Washington, DC, USA.

11. Ranganna S (1986) Handbook of Analysis and Quality Control of Fruit and Vegetable Products, Tata McGraw Hill Publishing Co. Lt. Delhi, India.

12. Bray HG, Thorpe WV (1954) Standard methods of biochemical analysis, Kalyani Publishers, New Delhi, India.

13. Joshi VK (2006) Sensory Science: Principles and Application in Food Evaluation. Agrotech Publishing Academy, Jaipur, India.
14. Susana Solorzano Morán, Irán Alia Tejacal, Fernando Rivera Cabrera, Víctor LópezMartínez, Laura Josefina Pérez Flores, et al. (2015) Quality attributes and functional compounds of Mexican plum (Spondiaspurpurea L.) fruit ecotypes. Fruits 70(5): 261-270.

15. Klimczak I, Malecka M, Szlachta M, Gliszczynska SA (2007) Effect of storage on the content of polyphenols, vitamin $\mathrm{C}$ and the antioxidant activity of orange juices. J Food Compost Anal 20(3-4): 313-322.

16. Kim DO, Lee KW, Lee HJ, Lee CY (2002) Vitamin C equivalent antioxidant capacity (VCEAC) of phenolic phytochemicals. J Agric Food Chem 50: 3713-3717.

17. Gardner PT, White TAC, Mc Phail DB, Duthie GG (2000) The relative contributions of vitamin $\mathrm{C}$, carotenoids and phenolics to the antioxidant potential of fruit juices. Food Chem 68: 471-474.

18. Sulaiman S, Ibrahim D, Kassim J, Hong LS (2011) Antimicrobial and antioxidant activities of condensed tannin from Rhizophoraapiculata barks. J Chem Pharm Res 3(4): 436-444.

19. Mishra SL, Sinhamahapatra PK, Nayak A, Das R, Sannigrahi S (2010) In vitro antioxidant potential of different parts of Oxoxylumindicum: A comparative study. Indian J Pharm Sci 72(2): 267-269.

20. Deka BC, Sethi V, Joya S (2005) Changes in quality of mango-pineapple spiced beverage during storage. Indian J Hort 71-75.

21. Sahu C, Patel S, Choudhary PL (2005) Technology for manufacture of whey based mango-herbal (lemon grass) beverage. J Food Sci Technol 42: 421-424.

22. Kannan S, Banumathi P (2005) Studies on preparation and storage of spiced RTS from Tamarind fruit. Bev Food World. 32: 40-41.

23. Srividya N, Ramachandran P $\quad$ (2012) Quality evaluation and antioxidant potential of papaya rts spiced beverage. Res J Pharm Bio Chem Sci 3(4): 460-466. 
For possible submissions Click Here

Your subsequent submission with Crimson Publishers will attain the below benefits

- High-level peer review and editorial services

- Freely accessible online immediately upon publication

- Authors retain the copyright to their work

- Licensing it under a Creative Commons license

- Visibility through different online platforms

- Global attainment for your research

- Article availability in different formats (Pdf, E-pub, Full Text)

- Endless customer service

- Reasonable Membership services

- Reprints availability upon request

- One step article tracking system 